\title{
Association study between growth hormone receptor (GHR) gene polymorphisms and obesity in Korean population
}

\author{
Seung-Ae Yang* \\ College of Nursing, Sungshin Women's University, Seoul, Korea
}

A main target of growth hormone $(\mathrm{GH})$ is adipose tissue in human body. The GH secretion in obesity patients is impaired. It is needless to say that growth hormone receptor (GHR) is necessary in $\mathrm{GH}$ hormone signaling. The purpose of the present study is to examine the association between single nucleotide polymorphisms (SNPs) and the development of obesity. A total of 211 overweight/obese subjects with a body mass index (BMI) $\geq 23 \mathrm{~kg} / \mathrm{m}^{2}$ and 157 nonoverweight/obese controls with a BMI of $18.5-23.0 \mathrm{~kg} / \mathrm{m}^{2}$ were involved in this study. Seven SNPs including the rs6451620 (intron), rs4130114 (intron), rs4410646 (intron), rs6898743 (intron), rs4394131 (intron), rs6182 (Cys440Phe), and rs6184 (Pro579Thr) and rs2229765 SNPs of GHR gene were genotyped. Genotyping was performed using custom DNA chip. SNPStats was used to calculate the odds ratio, $95 \%$ confidence interval, and $P$-value. The link-

\section{INTRODUCTION}

Obesity is a severe social problem in Korea (Kang, 2013). Not only social and economic factors (Chung et al., 2016) but also other various risk factors are important factors affecting the pathophysiologic and developing process of obesity. And life style and psychological factors are also related to hormone changes in obesity (Azuma et al., 2015; Kim et al., 2016; Nordkap et al., 2016).

Growth hormone $(\mathrm{GH})$ is affected by psychological stress and many physiological stresses (He et al., 2015; Karaca et al., 2016). And GH action is related to body energy expenditure and body weight (Glad et al., 2015; Haruta et al., 2015; Liu et al., 2016). It is a major hormone in insulin resistance and body weight control. Therefore, GH is widely studied in many field of studies (Huang et al., 2016; Imran et al., 2016; Karaca et al., 2016). age disequilibrium block and haplotypes among seven SNPs were determined using Haploview version 4.2. Dominant, recessive, and log-additive genetic models were conducted for genetic analyzing. Among tested SNPs in GHR gene, rs4410646 and rs6898743 showed significant association with obesity (rs4410646, $P=0.02$ in dominant model and $P=0.036$ in log-additive model; rs6898743, $P=0.039$ in dominant model and $P=0.044$ in log-additive model). In summary, these results suggest that $G H R$ gene polymorphisms might play a role in the development of obesity in the Korean population.

Keywords: Overweight/obese, Obesity, Growth receptor hormone, GHR, Single nucleotide polymorphism
However, hormone signaling of GH needs growth hormone receptor (GHR) (Carter-Su et al., 2016) because GH is not a steroid hormone (Carter-Su et al., 2016), and its main function is related to signaling of GHR into a cell. GHR deficiency is related with obesity, diabetes and cancer risk is likely appears. Therefore deficient GHR may affect GH function to be less modulation signals. It may show a kind of decreased pituitary hormone situation, which cause higher risk of metabolic syndrome (Khang et al., 2016), because the studies suggest that GH function is related with GHR function. GHR deficiency is related with adiposity. One of the famous example is GHR-null (GHR[-/-]) mouse (Sackmann-Sala et al., 2014), which showed insulin sensitivity and increased adiposity.

Insulin sensitivity is another problem in obesity, and GH is a major hormone in insulin sensitivity (Galescu et al., 2016; Pog-

\footnotetext{
*Corresponding author: Seung-Ae Yang (iD http://orcid.org/0000-0002-6235-2752 College of Nursing, Sungshin Women's University, 2 Bomun-ro 34da-gil, Seongbuk-gu, Seoul 02844, Korea

Tel: +82-2-920-7728, Fax: +82-2-968-0560, E-mail: ewha63@sungshin.ac.kr Received: October 31, 2016 / Accepted: December 13, 2016
}

This is an Open Access article distributed under the terms of the Creative Commons Attribution Non-Commercial License (http://creativecommons.org/licenses/by-nc/4.0/) which permits unrestricted non-commercial use, distribution, and reproduction in any medium, provided the original work is properly cited. 
giogalle et al., 2016; Suda et al., 2016). GH deficiency may lead to obesity, fatty liver, and sarcopenia. Those are closely related keywords to obesity, and these studies suggest that polymorphisms of GHR gene may associate with obesity. However, genetic effect such as common variation of functional gene may also affect its function (Barrie et al., 2017; Rahim et al., 2016). Therefore, in this study, we investigated the relationship between genetic polymorphisms of GHR gene and obese vs. nonobese in a Korean population, to compare polymorphism effect of $G H R$ on obesity.

\section{MATERIALS AND METHODS}

\section{Study subjects}

Three hundred sixty-eight subjects who participated in a general health check-up program were enrolled in this study. The biochemical characteristics including fasting plasma glucose, fasted glycated hemoglobin, total cholesterol, and low-density lipoprotein cholesterol were measured. The values of biochemical test are shown in Table 1. Body mass index (BMI) is calculated based on the weight $(\mathrm{kg})$ divided by the square of height $(\mathrm{m})$ (Yang, 2015). All subjects were classified according to the classification of Korean Society for the Study of Obesity (underweight, $\mathrm{BMI}<18 \mathrm{~kg} / \mathrm{m}^{2}$; normal, BMI 18 to $<23 \mathrm{~kg} / \mathrm{m}^{2}$; moderately obese, BMI 23 to $<25 \mathrm{~kg} / \mathrm{m}^{2}$; obesity I, BMI 25 to $<30 \mathrm{~kg} / \mathrm{m}^{2}$; obesity II, BMI $\geq 30 \mathrm{~kg} / \mathrm{m}^{2}$ ). Two hundred eleven subjects with a $\mathrm{BMI} \geq 23 \mathrm{~kg} / \mathrm{m}^{2}$ were included in overweight/obese group (mean age \pm standard deviation, $44.7 \pm 6.4$ years) and 157 subjects with a BMI of $18.5-23.0 \mathrm{~kg} / \mathrm{m}^{2}$ in nonoverweight/obese control group (mean age \pm standard deviation, $43.6 \pm 6.2$ years).

\section{SNP selection and genotyping}

Genomic DNAs were extracted from peripheral bloods of all subjects by Roche DNA extraction kit (Roche Diagnostics Corp.,

Table 1. Clinical data of subjects included in the study

\begin{tabular}{lcc}
\hline Characteristic & $\begin{array}{c}\text { Control } \\
(\mathrm{n}=157)\end{array}$ & $\begin{array}{c}\text { Overweight/obesity } \\
(\mathrm{n}=211)\end{array}$ \\
\hline Age $(\mathrm{yr})$ & $43.6 \pm 6.2$ & $44.8 \pm 6.4$ \\
Body mass index $\left(\mathrm{kg} / \mathrm{m}^{2}\right)$ & $21.4 \pm 1.2$ & $25.6 \pm 2.0$ \\
Fasting plasma glucose $(\mathrm{mg} / \mathrm{dL})$ & $89.7 \pm 11.4$ & $93.8 \pm 14.8$ \\
HbA1c $(\%)$ & $5.3 \pm 0.4$ & $5.5 \pm 0.7$ \\
Total cholesterol (mg/dL) & $186.0 \pm 27.7$ & $196.9 \pm 34.1$ \\
LDL-C (mg/dL) & $108.8 \pm 28.3$ & $119.0 \pm 32.3$ \\
\hline
\end{tabular}

Values are presented as mean \pm standard deviation. $\mathrm{HbA1c}$, fasted glycated hemoglobin; LDL-C, low-density lipoprotein cholesterol.
Indianapolis, IN, USA) and quantified using nanodrop machine. We selected seven SNPs including the rs6451620 (intron), rs4130114 (intron), rs4410646 (intron), rs6898743 (intron), rs4394131 (intron), rs6182 (Cys440Phe), and rs6184 (Pro579Thr) and rs2229765 in GHR gene. Each SNP was genotyped using custom DNA chip. After that, each genotype of SNPs was analyzed using targeted genotyping analysis software GCOS software (Affymetrix).

\section{Statistical analysis}

To evaluate the odds ratio (OR), 95\% confidence interval (CI), and $P$-value, SNPStats (http://bioinfo.iconcologia.net/index.php) and IBM SPSS Statistics ver. 23.0 (IBM Co., Armonk, NY, USA) were used. Genetic models (dominant [major homozygous vs. heterozygous+minor homozygous], recessive [major homozygoustheterozygous vs. minor homozygous], and log-additive [major homozygous vs. heterozygous vs. minor homozygous] models) were applied (Kim et al., 2014; Zare et al., 2013). The haplotype analysis in linkage disequilibrium (LD) was performed using Haploview 4.2. The $P$-value less than 0.05 was considered as statistically significant.

\section{RESULTS}

To find genetic factors involved in the development of obesity, we performed an association study between polymorphisms of GHR gene and overweight/obese. Firstly, we calculated Hardy-Weinberg equilibrium (HWE) in tested polymorphisms of GHR gene. The genotype distributions of the tested seven SNPs of GHR gene were consistent with the HWE (rs6451620, $P=1.00$; rs4130114, $P=1.00$; rs4410646, $P=0.16$; rs6898743, $P=1.00 ;$ rs4394131, $P=1.00 ;$ rs6182, and rs6184, $P=1.00$; rs $2229765, P=1.00$, data not shown).

Tables 2 and 3 showed genotype and allele distributions of seven SNPs in GHR gene. Among tested seven SNPs of GHR gene, two SNPs (rs4410646 and rs6898743) revealed the significant association with obesity (rs4410646, OR, 1.68, 95\% CI, 1.09-2.60, $P=0.02$ in dominant model $[\mathrm{A} / \mathrm{A}$ genotype vs. $\mathrm{A} / \mathrm{C}$ genotype $+\mathrm{C} /$ C genotype] and OR, 1.38, 95\% CI, 1.02-1.87, $P=0.036$ in log-additive model $[\mathrm{A} / \mathrm{A}$ genotype vs. $\mathrm{A} / \mathrm{C}$ genotype vs. $\mathrm{C} / \mathrm{C}$ genotype] rs6898743, OR, $0.63,95 \% \mathrm{CI}, 0.41-0.98, P=0.039$ in dominant model $[\mathrm{C} / \mathrm{C}$ genotype vs. $\mathrm{C} / \mathrm{G}$ genotype $+\mathrm{G} / \mathrm{G}$ genotype] and OR, $0.73,95 \% \mathrm{CI}, 0.54-0.99, P=0.044$ in log-additive model $[\mathrm{C} / \mathrm{C}$ genotype vs. $\mathrm{C} / \mathrm{G}$ genotype vs. $\mathrm{G} / \mathrm{G}$ gentoype $]$ ).

However, the other five SNPs did not show any statistical sig- 
Table 2. Genotype analysis of polymorphisms in growth hormone receptor $(G H R)$ gene between overweight/obesity and control subjects

\begin{tabular}{|c|c|c|c|c|c|c|}
\hline SNPS & Genotype & Control & Overweight/obese & Models & OR $(95 \%$ CI) & $P$-value \\
\hline \multirow[t]{3}{*}{ rs6451620 intron } & $\mathrm{G} / \mathrm{G}$ & $52(33.5)$ & $82(38.9)$ & Dominant & $0.77(0.49-1.20)$ & 0.24 \\
\hline & $\mathrm{A} / \mathrm{G}$ & $76(49.0)$ & $102(48.3)$ & Recessive & $0.68(0.38-1.23)$ & 0.21 \\
\hline & $\mathrm{A} / \mathrm{A}$ & $27(17.4)$ & $27(12.8)$ & Log-additive & $0.79(0.58-1.08)$ & 0.14 \\
\hline \multirow[t]{3}{*}{ rs4130114 intron } & $\mathrm{T} / \mathrm{T}$ & $128(83.7)$ & $179(87.3)$ & Dominant & $0.77(0.42-1.40)$ & 0.39 \\
\hline & $\mathrm{G} / \mathrm{T}$ & $24(15.7)$ & $26(12.7)$ & Recessive & 0.00 (0.00-NA) & NA \\
\hline & $\mathrm{G} / \mathrm{G}$ & $1(0.6)$ & $0(0)$ & Log-additive & $0.75(0.42-1.35)$ & 0.33 \\
\hline \multirow[t]{3}{*}{ rs4410646 intron } & $\mathrm{A} / \mathrm{A}$ & $71(45.2)$ & $68(32.2)$ & Dominant & $1.68(1.09-2.60)$ & $0.02^{*}$ \\
\hline & $\mathrm{A} / \mathrm{C}$ & $63(40.1)$ & $103(48.8)$ & Recessive & 1.31 (0.74-2.32) & 0.35 \\
\hline & $\mathrm{C} / \mathrm{C}$ & $23(14.7)$ & $40(19.0)$ & Log-additive & $1.38(1.02-1.87)$ & $0.036^{*}$ \\
\hline \multirow[t]{3}{*}{ rs6898743 intron } & $\mathrm{C} / \mathrm{C}$ & $52(33.1)$ & $96(45.7)$ & Dominant & $0.63(0.41-0.98)$ & $0.039^{*}$ \\
\hline & $\mathrm{C} / \mathrm{G}$ & $77(49.0)$ & $86(41.0)$ & Recessive & 0.71 (0.40-1.28) & 0.26 \\
\hline & $\mathrm{G} / \mathrm{G}$ & $28(17.8)$ & $28(13.3)$ & Log-additive & $0.73(0.54-0.99)$ & $0.044^{*}$ \\
\hline \multirow[t]{3}{*}{ rs4394131 intron } & $\mathrm{T} / \mathrm{T}$ & $127(81.4)$ & $170(81.0)$ & Dominant & $1.06(0.62-1.83)$ & 0.82 \\
\hline & $A / T$ & $28(17.9)$ & $38(18.1)$ & Recessive & 1.51 (0.13-17.25) & 0.73 \\
\hline & $\mathrm{A} / \mathrm{A}$ & $1(0.6)$ & $2(1.0)$ & Log-additive & $1.08(0.65-1.78)$ & 0.78 \\
\hline \multirow[t]{3}{*}{ rs6182 Cys440Phe } & $\mathrm{G} / \mathrm{G}$ & 134 (85.3) & $187(89.0)$ & Dominant & $0.70(0.37-1.31)$ & 0.26 \\
\hline & $\mathrm{G} / \mathrm{T}$ & $22(14.0)$ & $23(10.9)$ & Recessive & 0.00 (0.00-NA) & 0.13 \\
\hline & $\mathrm{T} / \mathrm{T}$ & $1(0.6)$ & $0(0)$ & Log-additive & $0.67(0.37-1.23)$ & 0.20 \\
\hline \multirow[t]{3}{*}{ rs6184 Pro579Thr } & $\mathrm{C} / \mathrm{C}$ & 133 (85.3) & $179(88.6)$ & Dominant & 0.74 (0.39-1.39) & 0.35 \\
\hline & $\mathrm{A} / \mathrm{C}$ & $23(14.7)$ & $23(11.4)$ & Recessive & NA & NA \\
\hline & $A / A$ & $0(0)$ & $0(0)$ & Log-additive & NA & NA \\
\hline
\end{tabular}

Values are presented as number (\%).

SNP, single nucleotide polymorphism; OR, odds ratio; Cl, confidence interval; NA, not applicable.

${ }^{*} P<0.05$ significant association.

Table 3. Allele analysis of polymorphisms in growth hormone receptor (GHR) gene between overweight/obesity and control subjects

\begin{tabular}{|c|c|c|c|c|c|}
\hline SNPS & Allele & Control & Overweight/obese & OR (95\% CI) & $P$-value \\
\hline \multirow[t]{2}{*}{ rs6451620 intron } & G & $180(58.1)$ & $266(63.0)$ & 1 & \\
\hline & A & $130(41.9)$ & $156(37.0)$ & 0.812 (0.602-1.096) & 0.17 \\
\hline \multirow[t]{2}{*}{ rs4130114 intron } & $\mathrm{T}$ & $280(91.5)$ & $384(93.7)$ & 1 & \\
\hline & G & $26(8.5)$ & $26(6.3)$ & 0.729 (0.414-1.283) & 0.27 \\
\hline \multirow[t]{2}{*}{ rs4410646 intron } & A & $205(65.3)$ & $239(56.6)$ & 1 & \\
\hline & C & 109 (34.7) & $183(43.4)$ & $1.440(1.065-1.947)$ & $0.018^{*}$ \\
\hline \multirow[t]{2}{*}{ rs6898743 intron } & C & $181(57.6)$ & $278(66.2)$ & 1 & \\
\hline & G & $133(42.4)$ & $142(33.8)$ & $0.695(0.514-0.940)$ & $0.018^{*}$ \\
\hline \multirow[t]{2}{*}{ rs4394131 intron } & $\mathrm{T}$ & $282(90.4)$ & $378(90.0)$ & 1 & \\
\hline & A & $30(9.6)$ & $42(10.0)$ & 1.044 (0.638-1.710) & 0.86 \\
\hline \multirow[t]{2}{*}{ rs6182 Cys440Phe } & G & $290(92.4)$ & $397(94.5)$ & 1 & \\
\hline & $\mathrm{T}$ & $24(7.6)$ & $23(5.5)$ & 0.700 (0.387-1.265) & 0.24 \\
\hline \multirow[t]{2}{*}{ rs6184 Pro579Thr } & C & $289(92.6)$ & 381 (94.3) & 1 & \\
\hline & A & $23(7.4)$ & $23(5.7)$ & $0.759(0.417-1.379)$ & 0.37 \\
\hline
\end{tabular}

Values are presented as number $(\%)$.

SNP, single nucleotide polymorphism; $\mathrm{OR}$, odds ratio; $\mathrm{Cl}$, confidence interval; $\mathrm{NA}$, not applicable.

${ }^{*} P<0.05$ significant association.

nificant association with susceptibility of obesity.

In haplotype analysis, we found two haplotypes (GC and TA haplotype) of one LD block in GHR gene, which consisted of rs6182 and rs6184. But two haplotypes of GHR gene showed no statistical significant difference between the control group and the overweight/obese group (GC haplotype, $P=0.22$ and TA haplo- 
Table 4. Haplotype analysis of polymorphisms of growth hormone receptor $(G H R)$ gene between overweight/obesity and control subjects

\begin{tabular}{|c|c|c|c|c|c|c|c|}
\hline \multirow{2}{*}{ Haplotype } & \multirow{2}{*}{ Frequency } & \multicolumn{2}{|c|}{ Control } & \multicolumn{2}{|c|}{ Overweight/obese } & \multirow{2}{*}{ Chi-square } & \multirow{2}{*}{$P$-value } \\
\hline & & + & - & + & - & & \\
\hline GC & 0.933 & 289.0 & 25.0 & 397.9 & 24.1 & 1.482 & 0.22 \\
\hline TA & 0.062 & 23.0 & 291.0 & 23.0 & 399.0 & 1.079 & 0.30 \\
\hline
\end{tabular}

Haplotypes consist of rs6182 and rs6184.

type, $P=0.30)$ (Table 4).

\section{DISCUSSION}

In present study, seven SNPs in GHR gene were studied, however, only two intron SNPs of them were weakly associated with obesity (rs4410646 and rs6898743). The two SNPs were not similar in major/minor allele frequencies, however, both of them showed association to obesity in the dominant and log-additive models, and not in recessive model. Among the other SNPs, four SNPs (rs4130114, rs4394131, rs6182, and rs6184) displayed similar major/minor allele frequencies, and all of them showed no association with obesity.

Association between rs 4410646 SNP of GHR gene and obesity was previously found in previous study (Mong et al., 2010). They reported that rs4410646 was significantly associated with the body composition $(P=0.0044)$ and blood pressure factor scores $(P=0.00017)$ (Mong et al., 2010). They also found rs7703713 SNP may affect IGF-1 activity factor score. However, the SNP was not included in our study. Interestingly, in their study, $\mathrm{C}$ genotype was associated with less obesity. It was on the contrary to our study. Our result was that $\mathrm{C}$ genotype was associated with overweight/obese group.

In addition, the association between rs6898743 SNP of GHR gene and cancer were studied, and rs6898743 was associated with esophageal adenocarcinoma (McElholm et al., 2010; Ong et al., 2014). But there was no obesity study was found.

In general, our result may show only weak association of GHR SNPs and obesity susceptibility. However, some presumable results may support our results. A variation in GHR gene was studied in various anthropometry (Glad et al., 2015), and relationship to central obesity was found. However, in their discussion, deficit in GHR does not always directly show GH deficiency, because they found responses to exogeneous GH in deficient GHR. They suggested the complex and continuous lifelong relationship among GH sensitivity, GH secretion, and other metabolic mechanisms in normal GH-IGF1 axis.

Another example of complex GH sensitivity may be the white adipose tissue of GHR-null mice (Sackmann-Sala et al., 2014). They presented the insulin, leptin, adiponectin, and protein changes in enhanced insulin sensitivity (Sackmann-Sala et al., 2014). In addition, Beattie et al. (2002) reported that decreased binding affinity may not reflect biological activities in the protein of living organism.

To our knowledge, this is the first study to report the relationship between SNPs in the GHR gene and obesity by BMI. Our findings support that GHR may play a role in pathophysiologic signaling of obesity or other related diseases. And further study in a large numbers with more anthropometry will be needed to verify our findings.

\section{CONFLICT OF INTEREST}

No potential conflict of interest relevant to this article was reported.

\section{REFERENCES}

Azuma K, Adachi Y, Hayashi H, Kubo KY. Chronic psychological stress as a risk factor of osteoporosis. J UOEH 2015;37:245-253.

Barrie ES, Hartmann K, Lee SH, Frater JT, Seweryn M, Wang D, Sadee W. The CHRNA5/CHRNA3/CHRNB4 nicotinic receptor regulome: genomic architecture, regulatory variants, and clinical associations. Hum Mutat 2017;38:112-119.

Beattie J, Phillips K, Shand JH, Brocklehurst S, Flint DJ, Allan GJ. Sensitivity of hybrid ovine/rat $\mathrm{GH}$ receptors to oGH and rat $\mathrm{GH}$ in transfected FDC-P1 mouse myeloid cells in vitro. Mol Cell Biochem 2002;238:137143.

Carter-Su C, Schwartz J, Argetsinger LS. Growth hormone signaling pathways. Growth Horm IGF Res 2016;28:11-15.

Chung W, Lee S, Lim SJ, Kim J. Modifying effects of education on the association between lifestyle behaviors and the risk of obesity: evidence from South Korea. BMC Public Health 2016;16:1100.

Galescu OA, Crocker MK, Altschul AM, Marwitz SE, Brady SM, Yanovski JA. A pilot study of the effects of niacin administration on free fatty acid and growth hormone concentrations in children with obesity. Pe- 
diatr Obes 2016 Sep 21 [Epub]. https://doi.org/10.1111/ijpo.12184..

Glad CA, Carlsson LM, Melander O, Almgren P, Sjöström L, Nilsson S, Larsson I, Svensson PA, Johannsson G. The GH receptor exon 3 deleted/full-length polymorphism is associated with central adiposity in the general population. Eur J Endocrinol 2015;172:123-128.

Haruta I, Fuku Y, Kinoshita K, Yoneda K, Morinaga A, Amitani M, Amitani H, Asakawa A, Sugawara H, Takeda Y, Bowers CY, Inui A. Oneyear intranasal application of growth hormone releasing peptide-2 improves body weight and hypoglycemia in a severely emaciated anorexia nervosa patient. J Cachexia Sarcopenia Muscle 2015;6:237-241.

He FQ, Fang G, Wang B, Guo XJ, Guo CL. Perinatal stress effects on later anxiety and hormone secretion in male mandarin voles. Behav Neurosci 2015;129:789-800.

Huang CC, Chou D, Yeh CM, Hsu KS. Acute food deprivation enhances fear extinction but inhibits long-term depression in the lateral amygdala via ghrelin signaling. Neuropharmacology 2016;101:36-45.

Imran SA, Tiemensma J, Kaiser SM, Vallis M, Doucette S, Abidi E, Yip CE, De Tugwell B, Siddiqi F, Clarke DB. Morphometric changes correlate with poor psychological outcomes in patients with acromegaly. Eur J Endocrinol 2016;174:41-50.

Kang YS. Obesity associated hypertension: new insights into mechanism. Electrolyte Blood Press 2013;11:46-52.

Karaca Z, Tanrıverdi F, Ünlühızarcı K, Kelestimur F. GH and pituitary hormone alterations after traumatic brain injury. Prog Mol Biol Transl Sci 2016;138:167-191.

Khang AR, Ku EJ, Kim YA, Roh E, Bae JH, Oh TJ, Kim SW, Shin CS, Kim SY, Kim JH. Sex differences in the prevalence of metabolic syndrome and its components in hypopituitary patients: comparison with an age- and sex-matched nationwide control group. Pituitary 2016;19: 573-581.

Kim JH, Chang SM, Bae JN, Cho SJ, Lee JY, Kim BS, Cho MJ. Mental-physical comorbidity in Korean adults: results from a Nationwide General Population Survey in Korea. Psychiatry Investig 2016;13:496503.

Kim SK, Park HJ, Chung JH, Kim JW, Seok H, Lew BL, Sim WY. Association between interleukin 18 polymorphisms and alopecia areata in Koreans. J Interferon Cytokine Res 2014;34:349-353.

Liu Z, Cordoba-Chacon J, Kineman RD, Cronstein BN, Muzumdar R, Gong Z, Werner H, Yakar S. Growth hormone control of hepatic lipid metabolism. Diabetes 2016;65:3598-3609.
McElholm AR, McKnight AJ, Patterson CC, Johnston BT, Hardie LJ, Murray LJ; Finbar Group. A population-based study of IGF axis polymorphisms and the esophageal inflammation, metaplasia, adenocarcinoma sequence. Gastroenterology 2010;139:204-212.e3.

Mong JL, Ng MC, Guldan GS, Tam CH, Lee HM, Ma RC, So WY, Wong GW, Kong AP, Chan JC, Waye MM. Associations of the growth hormone receptor (GHR) gene polymorphisms with adiposity and IGF-I activity in adolescents. Clin Endocrinol (Oxf) 2010;73:313-322.

Nordkap L, Jensen TK, Hansen ÅM, Lassen TH, Bang AK, Joensen UN, Blomberg Jensen M, Skakkebæk NE, Jørgensen N. Psychological stress and testicular function: a cross-sectional study of 1,215 Danish men. Fertil Steril 2016;105:174-187.e1-2.

Ong J, Salomon J, te Morsche RH, Roelofs HM, Witteman BJ, Dura P, Lacko M, Peters WH. Polymorphisms in the insulin-like growth factor axis are associated with gastrointestinal cancer. PLoS One 2014;9: e90916.

Poggiogalle E, Lubrano C, Gnessi L, Mariani S, Lenzi A, Donini LM. Fatty liver index associates with relative sarcopenia and GH/ IGF- 1 status in obese subjects. PLoS One 2016;11:e0145811.

Rahim M, El Khoury LY, Raleigh SM, Ribbans WJ, Posthumus M, Collins $\mathrm{M}$, September AV. Human genetic variation, sport and exercise medicine, and achilles tendinopathy: role for angiogenesis-associated genes. OMICS 2016;20:520-527.

Sackmann-Sala L, Berryman DE, Lubbers ER, Zhang H, Vesel CB, Troike KM, Gosney ES, List EO, Kopchick JJ. Age-related and depot-specific changes in white adipose tissue of growth hormone receptor-null mice. J Gerontol A Biol Sci Med Sci 2014;69:34-43.

Suda K, Matsumoto R, Fukuoka H, Iguchi G, Hirota Y, Nishizawa H, Bando H, Yoshida K, Odake Y, Takahashi M, Sakaguchi K, Ogawa W, Takahashi Y. The influence of type 2 diabetes on serum GH and IGF-I levels in hospitalized Japanese patients. Growth Horm IGF Res 2016;29:4-10.

Yang SA. Association between exonic polymorphism (rs629849, Gly1619Arg) of IGF2R gene and obesity in Korean population. J Exerc Rehabil 2015;11:282-286.

Zare M, Shahtaheri SJ, Mehdipur P, Abedinejad M, Zare S. The influence of CYP1A1 and GSTM1 polymorphism on the concentration of urinary 1-hydroxypyrene in cPAHs exposed Iranian anode plant workers. Mol Cell Toxicol 2013;9:303-309. 